\title{
Human Milk-Derived Growth Factor Prevents Duodenal Ulcer Formation
}

\author{
SOTER DAI, MICHAEL KLAGSBRUN, AND YUEN W. SHING \\ Department of Pharmacology, Faculty of Medicine, University of Hong Kong [S.D.], Hong Kong, and \\ Departments of Biological Chemistry and Surgery, Children's Hospital and Harvard Medical School
} [M.K., Y.W.S.], Boston, Massachusetts 02115

\begin{abstract}
Human milk was fractionated to obtain a partially purified growth factor preparation. The growth factor in this fraction, designated as human milk growth factor III, exhibits chromatographic and biological characteristics similar to epidermal growth factor-urogastrone. Pretreatment of mice with human milk growth factor III significantly reduces the incidence, number, total length, and severity score of cysteamine-induced duodenal ulcers. (Pediatr Res 19: 916-918, 1985)
\end{abstract}

\section{Abbreviations}

HMGF, human milk growth factor EGF, epidermal growth factor

Human milk is a source of growth factor activity (1) and contains at least three species of growth factors (2). The predominant one, designated as HMGF III, accounts for about $75 \%$ of the total growth factor activity in milk and is an acid-stable polypeptide with a mol wt of about 6000 and an isoelectric point of between 4.4 and $4.7(2-4)$. These structural characteristics, along with Carpenter's (5) finding that about $70 \%$ of the growth factor activity in human milk can be neutralized by antibody directed against human EGF, strongly suggest that EGF or a closely related polypeptide is the major growth factor in human milk. EGF, a polypeptide first isolated from submaxillary glands (6), was found to be structurally similar to urogastrone, a polypeptide prepared from urine (7). EGF-urogastrone is a potent mitogen for a variety of cells (8) and is known to stimulate the growth and maturation of the intestinal mucosa $(9,10)$. Besides being a mitogen, EGF-urogastrone is an inhibitor of gastric acid secretion (11) and has been used to promote healing of ulcers (12). Moreover, EGF-urogastrone has been localized by immunostaining in the duodenal (Brunner's) glands $(13,14)$. Specific receptors for EGF-urogastrone have been demonstrated in intestinal epithelial cells (15). Such findings suggest that EGFurogastrone plays a role in the secretion and growth of the gastrointestinal tract. Recently, Kirkegaard et al. (16) reported that EGF significantly inhibits the formation of cysteamineinduced duodenal ulcer in the rat. A similar activity in human milk would be of physiological interest since it would suggest that defined macro-molecular factors in human milk are capable of having an effect on the gastrointestinal tract of the human infant. This report demonstrates that a partially purified HMGF III is capable of protecting mice against the formation of duodenal ulcers induced by cysteamine in a dose-dependent manner.

Received January 7. 1985: accepted April 22, 1985.

Address correspondence to Dr. Yuen W. Shing. Enders 1010. The Children's Hospital, 300 Longwood Avenue, Boston. MA 02115.

Supported by NICHHD Grant HD-1 3585.

\section{MATERIALS AND METHODS}

Human milk was kindly provided by Dr. Cutberto Garza of the Baylor College of Medicine, Houston, TX. HMGF III was prepared as previously described (2). In brief, about $100 \mathrm{ml}$ of human milk was centrifuged at $13,000 \times g$ for $60 \mathrm{~min}$ at $4^{\circ} \mathrm{C}$. The fat at the top of the centrifuge tube and the cells and debris at the bottom were discarded. The skimmed milk was acidified by adjusting the $\mathrm{pH}$ to 4.3 with $\mathrm{HCl}$ and centrifuged at 30,000 $\times g$ for $60 \mathrm{~min}$ to remove precipitate. The supernatant fraction, which contained about $1.5 \mathrm{~g}$ of protein determined by the method of Lowry et al. (17), was dialyzed against distilled $\mathrm{H}_{2} \mathrm{O}$ and lyophilized. The lyophilized sample was then resuspended in $20 \mathrm{ml}$ of $0.1 \mathrm{M} \mathrm{NaCl}$ and $0.01 \mathrm{M}$ sodium acetate, $\mathrm{pH} 4.3$ and chromatographed in a Sephadex G-100 column $(5 \times 90 \mathrm{~cm})$ equilibrated with the same buffer. Fractions of $18 \mathrm{ml}$ were collected, measured for absorbance at $280 \mathrm{~nm}$, and tested for the ability to stimulate DNA synthesis in confluent quiescent monolayers of BALB/c 3T3 cells as previously described (18).

The molecular weights of HMGF III and purified mouse EGF (Collaborative Research, Waltham, MA) were determined by size exclusion chromatography on high-pressure liquid chromatography TSK 3000 columns $(7.5 \mathrm{~mm}$ ID $\times 50 \mathrm{~cm}$, Varian, Palo Alto, $\mathrm{CA}$ ) equilibrated with $6 \mathrm{M}$ guanidine- $\mathrm{HCl}, 5 \mathrm{mM}$ dithiothreitol and $0.02 \mathrm{M} 2$-(N-morpholino) ethane sulfonic acid, $\mathrm{pH}$ 6.5. About $4 \mathrm{mg}$ of HMGF III prepared by Sephadex G-100 gel filtration was resuspended in $100 \mu \mathrm{l}$ of equilibration buffer and applied to the column. High-pressure liquid chromatography was carried out at room temperature at a flow rate of $1 \mathrm{ml} / \mathrm{min}$. Fractions of $0.85 \mathrm{ml}$ were dialyzed against distilled $\mathrm{H}_{2} \mathrm{O}$ and tested for the ability to stimulate DNA synthesis in BALB/c 3T3 cells. Molecular weight markers used were blue dextran (mol wt, $\left.2 \times 10^{6}\right)$, bovine serum albumin ( $\left.\mathrm{mol} \mathrm{wt}, 67,000\right)$, ovalbumin (mol wt, 43,000), myoglobin ( $\mathrm{mol} \mathrm{wt}, 17,800$ ), ribonuclease (mol wt, 13,700) trasylol (mol wt, 6,200), and insulin (mol wt, 5,800).

Duodenal ulcers were induced in male CD-1 mice (body weight 20-25 g, Charles River, Wilmington, MA) by two subcutaneous injections of cysteamine $\mathrm{HCl}(350 \mathrm{mg} / \mathrm{kg})$, the second injection being given $7 \mathrm{~h}$ after the first. Cysteamine $\mathrm{HCl}$ (Aldrich, WI) was freshly prepared in saline at a concentration of $35 \mathrm{mg} / \mathrm{ml}$. The mice were randomly divided into groups of about 12 . Ten minutes prior to each cysteamine injection, groups of mice were pretreated with subcutanzous injections of either saline $(10 \mathrm{ml} /$ $\mathrm{kg})$, atropine sulfate $(10 \mathrm{mg} / \mathrm{kg})$, or HMGF III in various concentrations $(0.5,2,8,32$, and $128 \mathrm{mg} / \mathrm{kg})$. Twenty-four hours after the first cysteamine injection, the mice were sacrificed by rapid cervical dislocation and their duodena were removed. The duodena were opened along the antimesenteric side and examined under a dissecting microscope (Nikon, Japan) for mucosal lesions. The following four parameters of duodenal ulceration were measured: 1) The incidence of mucosal lesions was determined in each group. 2) The number of mucosal lesions was counted in each mouse. 3) The mucosal lesions were measured at their greatest length and the total length of lesions was esti- 


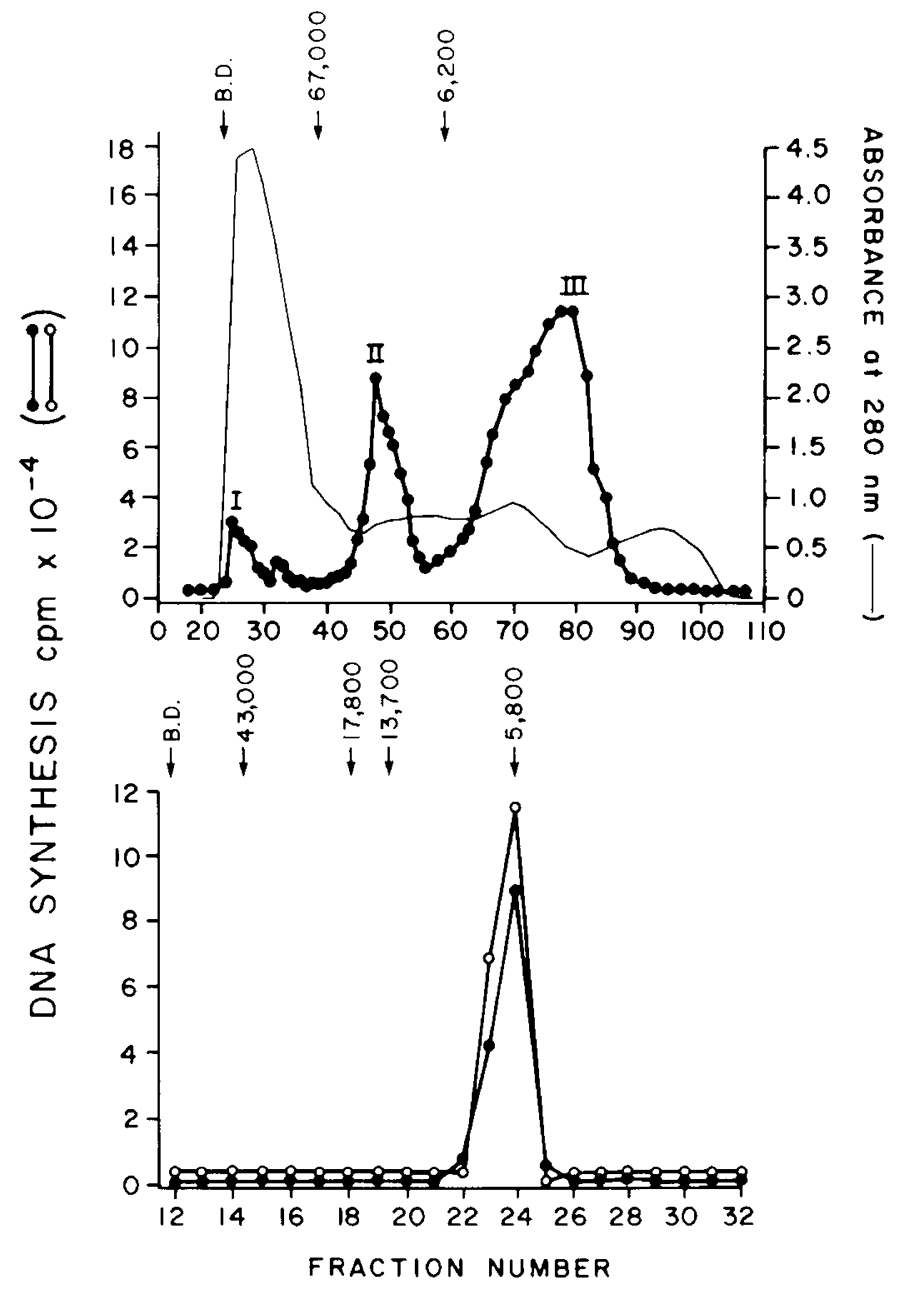

Fig. 1. Isolation and analysis of human milk-derived growth factor. Defatted, acellular milk was acidified to $\mathrm{pH} 4.3$ and the precipitate formed was removed by centrifugation. The supernatant fraction was chromatographed on a Sephadex G-100 column (top panel) as described in "Materials and methods." Fractions were collected, measured for absorbance at $280 \mathrm{~nm}$, and tested for the ability to stimulate DNA synthesis in 3T 3 cells. Partially purified HMGF III ( $4 \mathrm{mg} / 100 \mu 1$, obtained from fractions of the activity peak labeled III) was further analyzed on a high-pressure liquid chromatography size exclusion column (bottom panel) as described in "Materials and methods." Purified mouse EGF $(20 \mu \mathrm{g} / 100 \mu \mathrm{l})$ was also analyzed in the same manner for comparison. Fractions were collected, dialyzed. and tested for the ability to stimulate DNA synthesis in 3 T 3 cells. HMGF III (-) : mouse EGF $(\mathrm{O}-\mathrm{O})$. mated for each mouse. 4) The severity of ulcers was assessed using the scoring system of Smith (19): 0-normal; 1-superficial mucosal erosion; 2-hemorrhagic ulcer; and 3-perforation. The incidence of duodenal ulcers was evaluated using a $\chi^{2}$ test. The number, total length, and severity of ulcers were analyzed with a Student's $t$-test. The ulcer index was calculated by adding the severity score to the incidence of duodenal ulcers multiplied by $2(20)$.

\section{RESULTS}

When defatted, acidified human milk was fractionated by gel filtration on Sephadex G-100 column (Fig. 1, top panel) three peaks of growth factor activity were observed. The third peak in descending order of mol wt contained about $75 \%$ of the total growth factor activity in human milk and was designated as HMGF III. The molecular weight of HMGF III was more accurately determined by high-pressure liquid chromatography on a size exclusion column (Fig. 1, bottom panel). It had a mol wt of about 6000 and comigrated with mouse EGF. HMGF III, partially purified by Sephadex G-100 column chromatography, was tested as an antiulcer agent.

Two subcutaneous injections of cysteamine separated by an interval of $7 \mathrm{~h}$ caused duodenal lesions in $62.5 \%$ of the 16 mice treated (Table 1). These lesions, varying from superficial mucosal erosions to marked hemorrhagic ulceration, were located in the anterior duodenal wall and close to the pylorus. Pretreatment of mice with atropine prior to cysteamine injections significantly protected them from cysteamine-induced duodenal ulceration. All parameters of ulceration were markedly reduced and the ulcer index was 0.72 compared to 2.77 for those mice which received cysteamine without atropine pretreatment. These results demonstrated that cysteamine-induced ulcers were responsive to a well known antiulcer agent $(21,22)$.

HMGF III significantly reduced the incidence, number, and total length, as well as the severity score, of cysteamine-induced duodenal ulcers in a dose-dependent manner (Table 1). At 32 $\mathrm{mg} / \mathrm{kg}$ all parameters were significantly reduced. HMGF III at this level appeared equally as effective as atropine as an antiulcer agent. There was no mortality among the 86 mice treated.

\section{DISCUSSION}

This report demonstrates that, in mice pretreated with HMGF III, all parameters of the cysteamine-induced duodenal ulcers are significantly reduced in a dose-dependent manner. These results are in agreement with those reported earlier by Kirkegaard et al. (16). They were able to demonstrate that intraduodenal infusion of exogenous EGF inhibits the formation of cysteamine-induced duodenal ulcer in the rat. The cysteamine-induced duodenal

Table 1. Effects of HMGF III on cysteamine-induced duodenal ulcers in mice*

\begin{tabular}{|c|c|c|c|c|c|c|}
\hline \multirow[b]{2}{*}{$\begin{array}{l}\text { Pretreatment with two } \\
\text { subcutaneous injections of }\end{array}$} & \multirow[b]{2}{*}{$n$} & \multicolumn{5}{|c|}{ Duodenal ulcers } \\
\hline & & $\begin{array}{c}\text { Incidence } \\
(\%)\end{array}$ & $\begin{array}{l}\text { Number of } \\
\text { ulcers }\end{array}$ & $\begin{array}{l}\text { Total length } \\
(\mathrm{mm})\end{array}$ & $\begin{array}{l}\text { Severity } \\
\text { score }\end{array}$ & $\begin{array}{l}\text { Ulcer } \\
\text { indext }\end{array}$ \\
\hline \multicolumn{7}{|l|}{ Saline } \\
\hline $10 \mathrm{ml} / \mathrm{kg}$ & 16 & 62.50 & $1.19 \pm 0.29$ & $1.15 \pm 0.23$ & $1.52 \pm 0.33$ & 2.77 \\
\hline \multicolumn{7}{|l|}{ Atropine sulfate } \\
\hline $10 \mathrm{mg} / \mathrm{kg}$ & 11 & $18.18 \div$ & $0.18 \pm 0.12 \S$ & $0.25 \pm 0.17 \|$ & $0.36 \pm 0.24 \S$ & 0.72 \\
\hline \multicolumn{7}{|l|}{ HMGF III (mg/kg) } \\
\hline 0.5 & 12 & 66.67 & $1.08 \pm 0.30$ & $1.33 \pm 0.36$ & $1.51 \pm 0.33$ & 2.84 \\
\hline 2 & 12 & 58.33 & $1.00 \pm 0.30$ & $0.88 \pm 0.27$ & $1.14 \pm 0.31$ & 2.31 \\
\hline 8 & 12 & 33.33 & $0.33 \pm 0.14+$ & $0.35 \pm 0.19 \div$ & $0.83 \pm 0.37$ & 1.50 \\
\hline 32 & 11 & $18.18+$ & $0.27 \pm 0.19 \S$ & $0.26 \pm 0.18 \S$ & $0.32 \pm 0.22 \S$ & 0.68 \\
\hline 128 & 12 & $16.67 \S$ & $0.25 \pm 0.18 \div$ & $0.29 \pm 0.19 \S$ & $0.33 \pm 0.22 \S$ & 0.66 \\
\hline
\end{tabular}

* The values of number of ulcers, total length. and severity score are means \pm SEM.

+ Ulcer index $=$ the sum of the arithmetic mean of the severity score in a group and the incidence of duodenal ulcer multiplied by 2 .

$\$ p<0.05 . \$ p<0.02$. $\| p<0.01$ when compared with the corresponding values in saline control. 
ulcer in the rat has been used widely as a model of peptic ulcer disease. It resembles duodenal ulcer in man in its characteristic location, histological appearance, and some aspects of pathophysiology $(20,23)$. It has been reported that mice are slightly less sensitive to cysteamine ulcerogenesis than rats, but the ulcers induced in mice have a similar location, histopathology, and drug responses to those induced in rats (19). However, the cysteamine model in mice has the advantage of lower drug consumption and, therefore, has been advocated as a screening test for antipeptic ulcer activity in novel compounds. In our experiments, partially purified HMGF III was used because not enough pure growth factor was available to treat the large number of mice. Therefore, there is no conclusive proof as yet that it is the growth factor that prevents ulcers. However, the structural similarities of HMGF III to EGF-urogastrone, which is an anionic polypeptide with a mol wt of about 6000 and a well known antiulcer reagent (24), strongly suggests that it is the growth factor responsible for the antiulcer effect. Whether HMGF III and EGF-urogastrone are identical or structurally similar polypeptides will require amino acid sequencing analysis.

HMGF III was given to mice subcutaneously rather than orally because subcutaneous administration is a much more efficient technique for growth factor delivery. However, the resistance of HMGF III to inactivation by $\mathrm{HCl}, \mathrm{pH} 1$ (3), and the presence of trypsin inhibitors in human milk (25) make it plausible that this growth factor could survive passage through the gastrointestinal tract. Thus the antiulcer effect of HMGF III might be one of the protective mechanisms that human milk is postulated to have for the breast-fed infant.

\section{REFERENCES}

1. Klagsbrun M 1978 Human milk stimuates DNA synthesis and cellular proliferation in cultured fibroblasts. Proc Natl Acad Sci USA 75:5057-5061

2. Shing YW. Klagsbrun M 1984 Human and bovine milk contain different sets of growth factors. Endocrinology 115:273-282

3. Klagsbrun M. Shing Y 1984 Growth promoting factors in human and bovine milk. In: Guroff G (ed) Growth and Maturation Factors, Vol 2. John Wiley \& Sons, New York, pp 161-192

4. Shing YW, Klagsbrun M 1984 Isolation of growth factors from human milk In: Barnes DW. Sirbasku DA. Sato GH (eds) Cell Culture Methods for Molecular and Cell Biology, Vol 1. Alan R. Liss, New York, pp 159-179

5. Carpenter G 1980 Epidermal growth factor is a major growth-promoting agent in human milk. Science 210:198-199

6. Cohen S 1962 Isolation of a mouse submaxillary gland protein accelerating incisor eruption and eyelid opening in the newborn animal. $\mathrm{J}$ Biol Chem 237:1555-1562

7. Gregory H 1975 Isolation and structure of urogastrone and its relationship to epidermal growth factor. Nature 257:325-327

8. Carpenter G, Cohen S 1979 Epidermal growth factor. Ann Rev Biochem 48:193-216

9. Malo C. Ménard D 1982 Influence of epidermal growth factor on the development of suckling mouse intestinal mucosa. Gastroenterology 83:28-35

10. Calvert R, Beaulieu JF, Ménard D 1982 Epidermal growth factor (EGF) accelerates the maturation of fetal mouse intestinal mucosa in utero. Experientia 38:1096-1097

11. Bower JM, Camble R, Gregory H, Gerring EL, Willshire IR 1975 The inhibition of gastric acid secretion by epidermal growth factor. Experientia 31:825826

12. Gregory H, Bower JM, Willshire IR 1977 Urogastrone and epidermal growth factor. In: Kastrup KW, Nielsen JH (eds) Growth Factors. Pergamon Press, Elmsfeld, NY, pp 75-84

13. Elder JB, Williams G, Lacey E, Gregory H 1978 Cellular localisation of human urogastrone/epidermal growth factor. Nature 271:466-467

14. Heitz PU, Kasper M, Van Noorden S, Polak JM, Gregory H, Pearse AGE 1978 Immunohistochemical localisation of urogastrone to human duodenal and submandibular glands. Gut 19:408-413

15. Forgue-lafitte ME, Laburthe M, Chamblier MC, Moody AJ, Rosselin G 1980 Demonstration of specific receptors for EGF-urogastrone in isolated rat intestinal epithelial cells. FEBS Lett 114:243-246

16. Kirkegaard P, Skov Olsen P, Seier Poulsen S, Nex $\phi$ E 1983 Epidermal growth factor inhibits cysteamine-induced duodenal ulcers. Gastroenterology $85: 1277-1283$

17. Lowry OH, Rosenbrough NJ, Farr AL, Randall RJ 1951 Protein measurement with the folin phenol reagent. J Biol Chem 193:265-275

18. Klagsbrun M, Langer R, Levenson R, Smith S, Lillehei C 1977 The stimulation of DNA synthesis and cell division in chondrocytes and 3T3 cells by a growth factor isolated from cartilage. Exp Cell Res 105:99-108

19. Smith JA 1983 The effect of atropine, cimetidine and FPL 52694 on duodenal ulcers in mice. Eur J Pharmacol 88:215-221

20. Szabo S 1978 Animal model: cysteamine-induced acute and chronic duodenal ulcer in the rat. Am J Pathol 93:273-276

21. Dai S, Ogle CW 1974 Gastric ulcers induced by acid accumulation and by stesss in pylorus-occluded rats. Eur J Pharmacol 26:15-21

22. Dai S, Ogle CW, Lo CH 1975 The effects of metiamide on gastric secretion and stress ulceration in rats. Eur J Pharmacol 33:277-282

23. Seier Poulsen S, Szabo S 1977 Mucosal surface morphology and histological changes in the duodenum of the rat following administration of cysteamine. Br J Exp Pathol 56:1-8

24. Hollenberg MD 1979 Epidermal growth factor-urogastrone, a polypeptide acquiring hormonal status. Vitam Horm 37:69-110

25. Laskowski M Jr, Laskowski M 1951 Crystalline trypsin inhibition from colostrum. J Biol Chem 190:563-573 